Rev. Int. Contam. Ambie. 33 (Especial Biotecnología e ingeniería ambiental) 115-123, 2017

DOI: 10.20937/RICA.2017.33.esp01.10

\title{
EVALUATION OF POLYHYDROXYALKANOATES PRODUCING BACTERIA ISOLATED FROM SOILS WITH WASTES OF Cocos nucifera
}

\author{
Yanet ROMERO RAMÍREZ1*, Giovanni HERNÁNDEZ-FLORES ${ }^{2}$, \\ Miguel Ángel RODRÍGUEZ BARRERA ${ }^{3}$, Daniel SEGURA GONZÁLEZ ${ }^{4}$, \\ Nelda Xanath MARTÍNEZ GALERO ${ }^{5}$, Jeiry TORIBIO-JIMÉNEZ ${ }^{3}$, \\ Mildred CASTELLANOS ESCAMILLA ${ }^{6}$ and José Alberto HERNÁNDEZ ELIGIO ${ }^{7}$
}

${ }^{1}$ Universidad Autónoma de Guerrero. Avenida Lázaro Cárdenas, Ciudad Universitaria, Chilpancingo, Guerrero, México, Apdo Postal 39070

${ }^{2}$ Consejo Nacional de la Ciencia y la Tecnología-Unidad Académica de Ciencias de la Tierra, Universidad Autónoma de Guerrero. Ex Hacienda San Juan Bautista, Taxco el Viejo, Guerrero, México, C. P. 40323

${ }^{3}$ Laboratorio de Microbiología Molecular y Biotecnología Ambiental, Universidad Autónoma de Guerrero. Ex Hacienda San Juan Bautista, Taxco el Viejo, Guerrero, México, C.P. 40323

${ }^{4}$ Departamento de Microbiología Molecular, Instituto de Biotecnología, Universidad Nacional Autónoma de México. Avenida Universidad número 2001, Colonia Chamilpa, Cuernavaca, Morelos, México, C. P. 62210

${ }^{5}$ Universidad del Papaloapan, Campus Tuxtepec. Circuito Central número 200, colonia Parque Industrial, Tuxtepec, Oaxaca, México, C. P. 6830

${ }^{6}$ University of Calgary. 2500 University Drive NW, Calgary, Canadá, AB T2N 1N4

${ }^{7}$ Departamento de Ingeniería Celular y Biocatálisis, Instituto de Biotecnología, Universidad Nacional Autónoma de México. Avenida Universidad número 2001, Colonia Chamilpa, Cuernavaca, Morelos, México, C. P. 62210 *Corresponding author: yromero@uagro.mx

(Received March 2016; accepted July 2016)

Key words: Bacillus, PHAs, Staphylococcus

\begin{abstract}
Polyhydroxyalkanoates (PHAs) are polyesters produced and accumulated in prokaryotes as carbon and energy storage materials. These polymers can be used to produce biodegradable plastics. Actually, the industrial production of PHAs for the manufacture of biodegradable plastics has a high production cost due to the use of expensive carbon substrates. An alternative to reduce these costs is the use of wastes from renewable resources. Coconut biomass, which is the most abundant agroindustrial waste in the state of Guerrero, Mexico, has a promising potential as a primary or secondary feedstock for PHAs production. In this research, it is identified and evaluated the PHAs producing bacteria isolated from soil where Cocos nucifera waste and fiber in decomposition are accumulated. It was found six bacteria capable of producing PHAs in different concentrations ( 0.06 to $0.422 \mathrm{~g} / \mathrm{L}$ ). These strains belong to the genus Staphylococcus and Bacillus. The production of PHAs of Bacillus megaterium isolate S15 was characterized, and turned out to be the best PHAs accumulating bacterium. A bank of strains capable of producing polyhydroxyalkanoates was obtained for future studies.
\end{abstract}

Palabras clave: Bacillus, PHA, Staphylococcus 


\section{RESUMEN}

Los polihidroxialcanoatos (PHA) son poliésteres que se producen y acumulan como materiales de almacenamiento de carbono y energía en procariotas. Sin embargo, éstos pueden emplearse para producir plásticos biodegradables. Actualmente, la producción industrial de PHA para la manufacturación de plásticos biodegradables tiene un alto costo de producción debido al uso de sustratos de carbón caros. Una alternativa para reducir los costos es utilizando residuos como sustratos a partir de recursos renovables. La fibra de coco, que es uno de los residuos agroindustriales más abundantes en el estado de Guerrero, México, tiene un prometedor potencial como materia prima principal o secundaria para la producción de PHA. En esta investigación se identifica y evalúa a bacterias productoras de PHA aisladas de suelo donde residuos de Cocos nucifera se encuentran acumulados y en descomposición. Se aislaron seis cepas capaces de producir PHA en diferentes concentraciones (0.06-0.422 g/L). Se identificaron las cepas, mismas que pertenecen a los géneros de Staphylococcus y Bacillus. Se caracterizó la producción de PHA en Bacillus megaterium S15, la cual fue la mejor cepa para acumular este poliéster. Adicionalmente, se obtuvo un banco de cepas capaces de producir PHA para estudios futuros.

\section{INTRODUCTION}

Polyhydroxyalkanoates (PHAs) are produced and accumulated in prokaryotes as carbon and energy storage materials (Lee 1996, Rehm 2003, González García et al. 2013). The PHAs are aliphatic polyesters of $\beta$-hydroxy fatty acids where the hydroxyl group of a monomer, forms an ester with the hydroxyl group of the adjacent monomer (Madison and Huisman 1999). These biopolymers have great industrial potential since they have thermoplastic properties similar to conventional plastics derived from petroleum, they are also biocompatible and biodegradable (Lee 1996, Chen 2009, Akaraonye et al. 2010). For this reason, some PHAs are already produced at an industrial scale for the manufacture of biodegradable plastics. PHAs can also be used in the biomedical field as suture filaments, drug carriers and regeneration devices and scaffolds for cell growth (Poirier et al. 1995, Zinn 2001, Lee et al. 2011, Shrivastav et al. 2013).

In agriculture they have been used as devices to release growth regulators, fertilizers or pesticides (Van der Walle et al. 2001). The PHAs are produced by more than 30 bacterial species (Slater et al. 1998, Takase 2003, Tsuge et al. 2007, Yang et al. 2011). Bacteria produce and accumulate PHAs under unbalanced growth conditions, for instance, in the presence of high concentrations of the carbon source and limitation of some other essential nutrient, such as nitrogen, oxygen, phosphorous and magnesium (Verlinden 2007). They are stored in granules within the cell, and their main function is as a reserve of nutrients and energy (Kichise et al. 2002, Pötter et al.
2002, Grage et al. 2009). The PHAs can be produced from renewable resources (Lee 1996, Steinbüchel and Hein 2001), but given the high cost of substrates and the processes for the production of PHAs at an industrial level, it is still critical to reduce the expensive costs (Choi and Lee 1997).

The use of bacteria for the production of biopolymers has become of a great relevance due to the benefits that they provide compared to plastics produced from petroleum. One of these benefits is that bacteria can produce PHAs from industrial wastes as carbon sources (Kourmentza et al. 2015). This is used as a strategy to reduce the production costs of the biodegradable plastics (Ponce Andrade et al. 2012). These economical carbon resources include: bagasse, methanol, wines and glycerol waste (Cavalheiro et al. 2009, Passanha et al. 2013, Hernández-Flores et al. $2015 \mathrm{a}, \mathrm{b}, \mathrm{c}, \mathrm{d})$.

Guerrero, is a state located in the southern part of Mexico, it is the first producer of Cocos nucifera. Therefore, a huge amount of waste is generated in its processing. The objective of this study was to isolate, characterize and evaluate PHAs producing bacteria isolated from coconut waste or fiber that could be used for the PHAs production process.

\section{MATERIALS AND METHODS}

\section{Site and waste sampling description}

The isolation of PHAs producing bacteria was conducted at a site with high concentrations of solid residues of Cocos nucifera located at Sabanillas, 
Guerrero, in southern Mexico $\left(17^{\circ} 34^{\prime} 1^{\prime \prime} \mathrm{N}, 9^{\circ} 23^{\prime}\right.$ $52 " \mathrm{~W}$ ). Four samples from soil (SS1 to SS4) below ground coconut waste, and three samples from fiber of decomposed coconut (CS1 to CS3) were collected and saved in aseptic screw capped bottles.

Isolation of strains, medium and growth conditions

A quantity of $1 \mathrm{~g}$ of soil or fiber of coconut from each of the collected samples was mixed in $9 \mathrm{~mL}$ of sterile saline solution $\left(\mathrm{NaCl}_{2} 0.85 \%\right.$ ), serial dilutions were made (1:1000 and 1:10 000). One hundred $\mu \mathrm{L}$ of each dilution was plated on Luria Bertani (LB) agar plates and incubated at $37^{\circ} \mathrm{C}$ for $48 \mathrm{~h}$. Colonies differing in morphological characteristics were selected. For the PHAs production, the cells were grown on $5 \mathrm{~g} / \mathrm{L}$ of peptone, $3 \mathrm{~g} / \mathrm{L}$ of yeast extract in a $\mathrm{pH}$ of 7.0 (PY), and supplemented with $2 \%$ of glucose. Liquid cultures were grown in 250-mL flasks containing $50 \mathrm{~mL}$ of medium, and incubated in a rotary shaker at 250 rpm and $37^{\circ} \mathrm{C}$.

\section{Staining procedures and microscopy}

Intracellular PHAs accumulation was screened using nile blue A staining (Sigma, St. Louis, Mo. USA) by the Ostle and Holt (1982) method. For staining, cells from early stationary growth phase were used. A $1 \%$ of aqueous solution of nile blue A, was mildly heated and filtered before use. Heat fixed smear cells were stained with a nile blue A solution at $55^{\circ} \mathrm{C}$ in water bath for $10 \mathrm{~min}$. After staining, slides were washed with tap water, followed by an $8 \%$ acetic acid solution for 1 min and then washed again. Finally the stained smear was blotted dry with bibulous paper (remoistened with tap water) and covered with a glass cover slip. Cells were examined by phase contrast microscopy (Olympus BX41). Electron-microscopy was carried out as previously reported (Mejia-Ruiz et al. 1997).

\section{PHA determination}

The PHAs were assayed by the Law and Slepecky (1961) method, as previously reported, using commercial polyhydroxybutyrate (PHB) as the standard (Segura and Spin 1998).

\section{DNA extraction, sequencing and phylogenetic analyses}

Genomic DNA was extracted by using a Gene$\mathrm{JeT}^{\mathrm{TM}}$ Genomic DNA purification kit (Thermo Scientific), according the manufacturer's instructions. Bacterial 16S rDNA was amplified by polymerase chain reaction (PCR) using the universal bacterial
16S rDNA primers fd1 5'-AGAGTTTGATCCTGGCTCAG-3' and rd1 5'-AAGGAGGTGATCCAGCC-3'. The PCR products were electrophoresed and purified, DNA sequences were determined by the dideoxy chain termination method (Sanger et al. 1977), with a Perkin Elmer/Applied biosystems DNA sequencer. A phylogenetic analysis of the recovered 16S rRNA gene sequences was performed using the ribosomal database project II (RPD II). The evolutionary distances were computed by the maximum composite likelihood method (Toribio-Jimenez et al. 2014). GenBank accession numbers for Bacillus thuringiensis 16S rDNA sequences are: KR902612 and KR902615, for Bacillus cereus 16S rDNA gene sequences are: KR902614 and KR902613, while for Bacillus megaterium 16S rDNA gene sequence is: KR902611, and for Staphylococcus saprophyticus 16S rDNA gene sequence is: KR902610.

\section{RESULTS AND DISCUSSION}

\section{Isolation and screening of polyhydroxyalkanoates- producing bacteria}

With the aim of finding new strain isolates from coconut waste capable of accumulating polyhydroxyalkanoates, dilutions of soil and washing of fiber of decomposing coconut waste samples were plated as described in "Materials and methods". Forty and 49 isolates were obtained from soil and fiber of coconut, respectively (Fig. 1).

A first screening to search for bacteria capable of producing polyhydroxyalkanoates was performed through the direct observation of the PHAs accumulation phenotype (opacity). Ten strains ( 8 of soil and 2 of fiber coconut) showed positive results, suggesting that they are efficient PHAs producers (Fig. 2)

In order to confirm PHAs accumulation by the phenotype, the strains were stained with nile blue A and examined by microscopy to visualize the PHAs granules. As shown in figure 3, the PHAs granules were observed in strains S218, S11, S213, S110, S15 and $\mathrm{C} 115$.

\section{Polyhydroxyalkanoates production}

Nile blue A revealed that the strains can produce PHAs, thus we carried out the quantification of the polymer. Strains were grown in PY medium to early stationary phase $(36 \mathrm{~h})$ and then the cells were collected to quantify the polymer. As reported in table I, the strains produce PHAs with different yields.

Particularly strains S15, S110 and C115 showed a better production of the polymer. Due to the 
a)

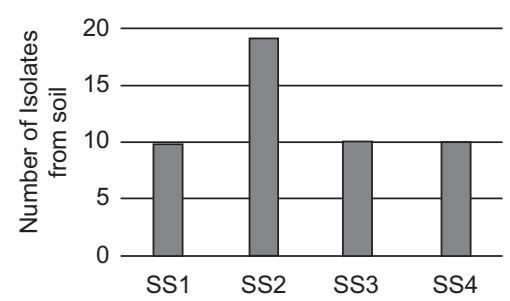

b)

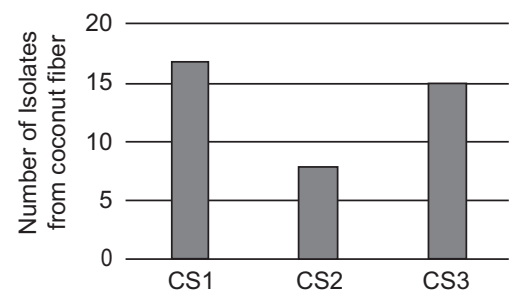

Fig. 1. Number of units formed of colony isolates from soil (A) and coconut fiber (B) samples. SS = samples from soil of decomposed coconut, $\mathrm{CS}=$ samples from fiber of decomposed coconut

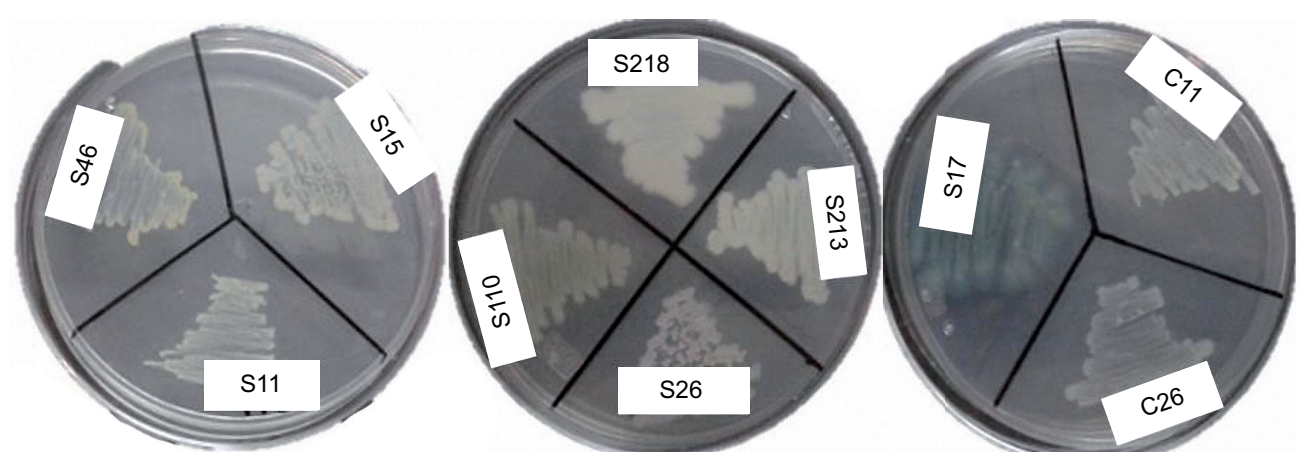

Fig 2. Opacity phenotype (Polyhydroxyalkanoates accumulation) of S46, S15, S11, S17, S218, S213, S110, S26 corresponding to strains isolated from soil, and C115 and C26 corresponding to strains isolated from fiber coconut
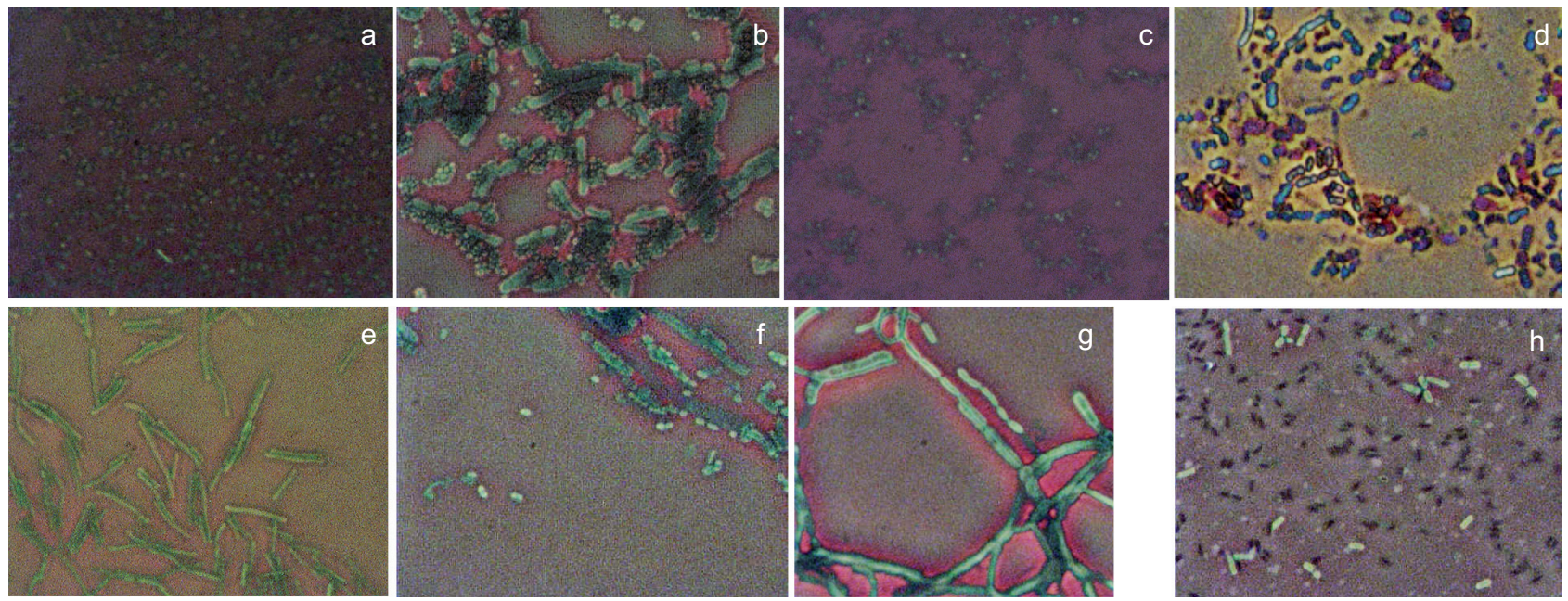

Fig. 3. Phase contrast microscopy of nile blue a stained polyhydroxyalkanoates granules within the cells C26 (A) and C115 (B) corresponding to strains isolated from coconut fiber, and S11 (C), S15 (D), S110 (E), S213 (F), S46 (G), S218 (H) corresponding to strains isolated from soil. In the figure only the microscopy of the isolate S46 is shown, however the isolates S17 and S26 (data not showed) had similar microscopy at the S46. 
TABLE I. POLYHYDROXYALKANOATES (PHA) PRODUCING BACTERIAS ISOLATES FROM SOILS WITH WASTES OF Cocos nucifera

\begin{tabular}{llc}
\hline Isolates & Specie & $\begin{array}{c}\text { PHA } \\
\text { Content }(\mathrm{mg} / \mathrm{mL})\end{array}$ \\
\hline C115 & Bacillus thuringiensis & 0.385 \\
S11 & Bacillus cereus & 0.310 \\
S15 & Bacillus megaterium & 0.422 \\
S110 & Bacillus thuringiensis & 0.403 \\
S213 & Staphylococcus saprophyticus & 0.063 \\
S218 & Bacillus cereus & 0.028 \\
\hline
\end{tabular}

All determinations were made in duplicate. PHAs content is reported in mg of PHAs by $\mathrm{mL}$ of medium. These bacteria were identified by molecular assays. $\mathrm{C}=$ samples from fiber of decomposed coconut, $\mathrm{S}=$ samples from soil of decomposed coconut

accumulation of PHAs of strain S15, we carried out a kinetic test of that production by growing the strain in PY medium. As shown in figure 4, S15 strain began to synthesize PHAs at $8 \mathrm{~h}$ and reached the maximum accumulation at $36 \mathrm{~h}$.

\section{Electron-microscopy of strain S15}

The PHAs production by strain S15 was higher than the others. Electron microscopic examination of the PHAs granules of strain S15 incubated in PY glucose medium was performed. As shown in figure 5, the polymer was accumulated in a large intracellular granule.

\section{S rRNA sequence analysis}

To characterize the isolated bacteria, their $16 \mathrm{~S}$ rDNA sequences were obtained by amplifying and sequencing their DNA fragments. The results from the analysis using the ribosomal database project II (RPD II), showed that the 16S rDNA sequences of all isolates, gather in two clusters (Fig. 6). The first one belongs to the Bacillus group and contains five isolates showing a $16 \mathrm{~S}$ rDNA sequence from $B$. megaterium (S15), B. thuringiensis (C115, and $\mathrm{S} 110$ ) and B. cereus (S11 and S218). The second one (S213) belongs to the Staphylococcus group and displays the same 16S rDNA sequence from $S$. saprophyticus.

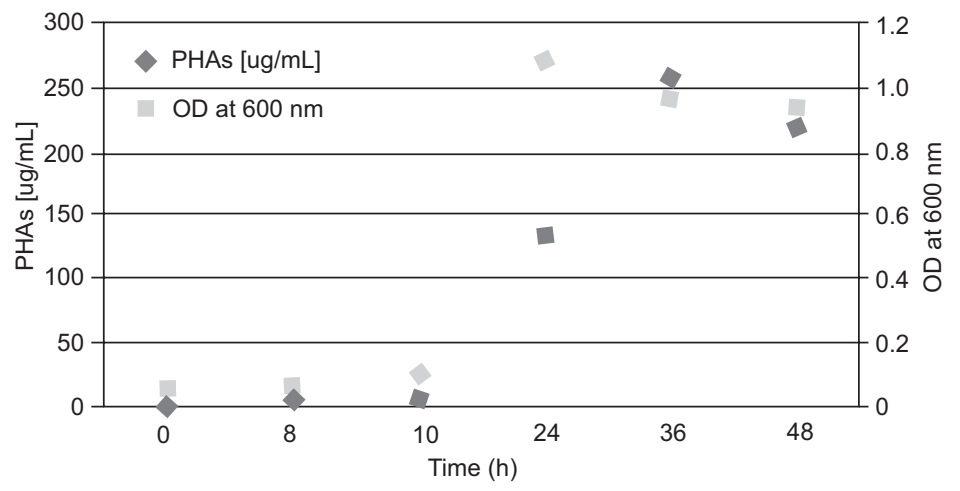

Fig. 4. Kinetic of polyhydroxyalkanoates (PHA) production and growth of Bacillus megaterium isolate $\mathrm{S} 15$. OD = optical density
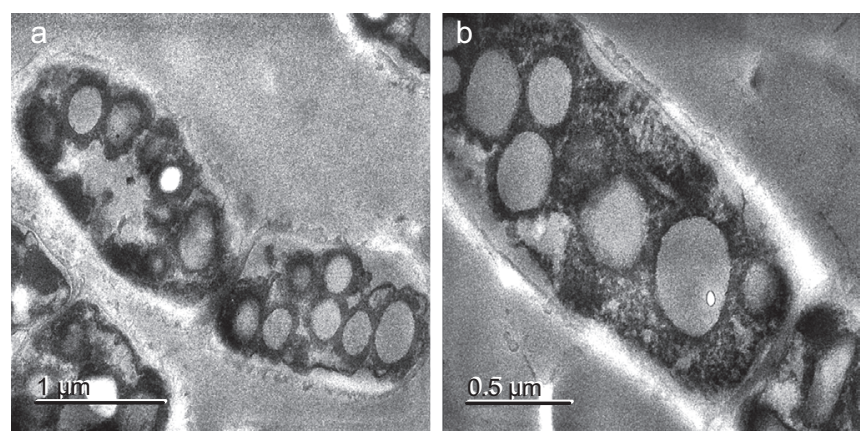

Fig. 5. Electron-microscopy of the polyhydroxyalkanoates granules accumulated by the strain Bacillus megaterium isolate S15 was observed in different campus A) and B) of the same sample. Bar, 1 and $0.5 \mu \mathrm{M}$. 


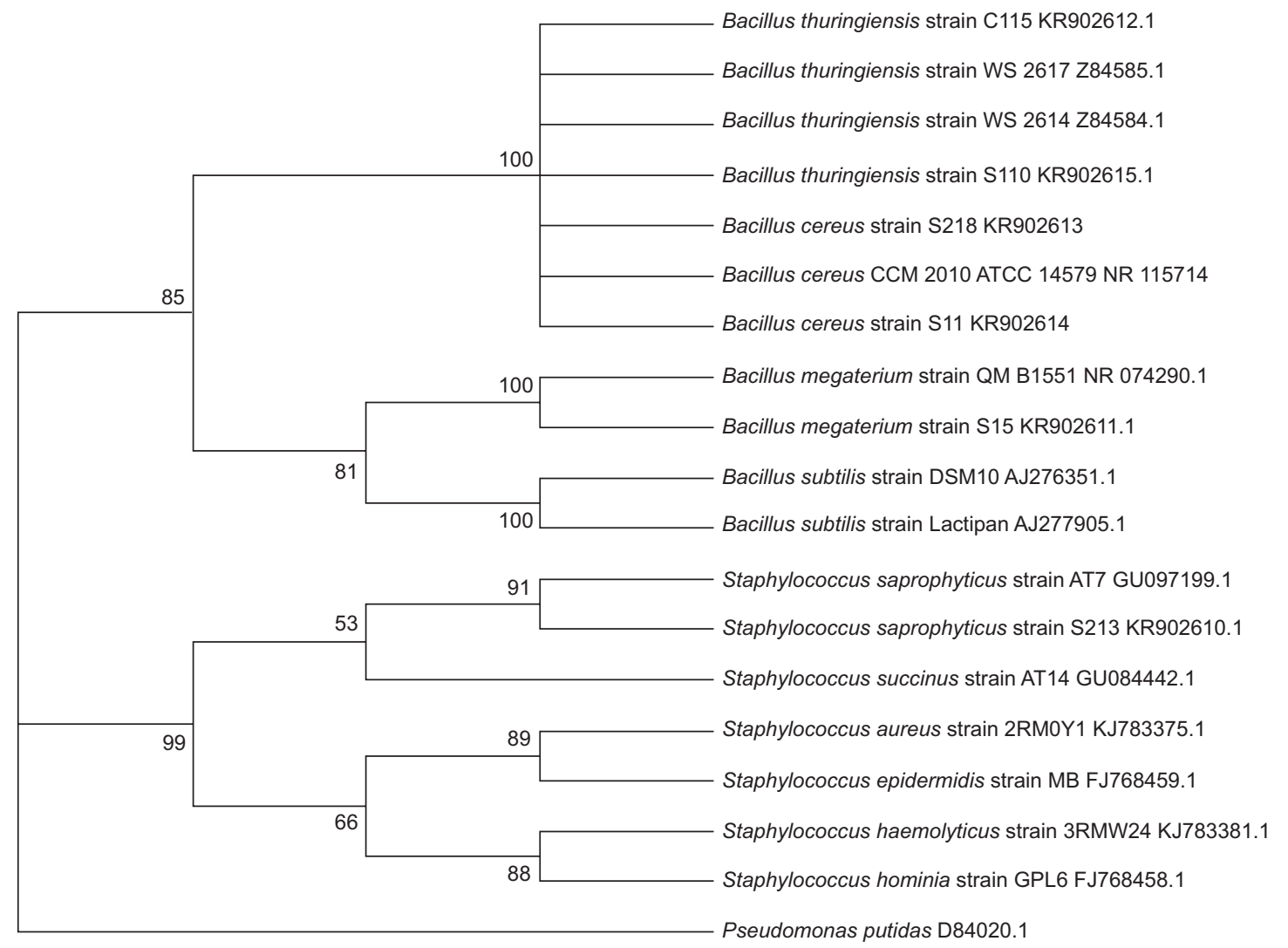

Fig. 6. Molecular phylogenetic analysis by the neighbor-joining method on $16 \mathrm{~S}$ gene sequences

The PHAs have similar material properties to conventional plastics, but also a complete biodegradability. For this reason, PHAs are desirable candidates for biodegradable plastics (Gumel et al. 2013). Actually, PHAs production processes that employ several bacteria have been focused on the development of sustainable 190 and rentable economical production of PHAs., although the PHAs production is expensive, mainly because of the type of carbon substrates it needs. The process can be made more competitive by using residues available at the factories, such as oil palm biomass effluent, fatty waste bagasse, methanol, wines and glycerol wastes (Cavalheiro et al. 2009, Povolo et al. 2012, Hassan et al. 2013, Passanha et al. 2013). Therefore, in this study we characterized PHAs producing bacteria isolated from soil with accumulation of coconut and its fibers to obtain a strain collection for future investigation about the PHAs production process using residues of coconut in the culture media. We found that seven of 10 isolates can accumulate PHAs. The data showed that the most persistent bacterial populations were members of two genera: Staphylococcus and Bacillus (Table I).
It is well known that many species from the genus Bacillus are typical PHAs producers but there are no reports about the genus Staphylococcus. The best PHAs producer obtained in this study was the strain S15 that was identified as Bacillus megaterium. Particularly, many PHAs producers can accumulate a high number of granules in cytoplasm such as, Alcaligenes, Azotobacter, Bacillus, Pseudomonas, Enterobacter, Necator, Rhodobacter, Aeromonas, Ralstonia and Cupriavidus (Reddy et al. 2003, Gao et al. 2013, Singh et al. 2013, Yun et al. 2013).

In this study, Bacillus megaterium strain S15 produced several large intracellular granules, this is consistent with the results reported by Liu et al. (2013). The production of this strain was high compared with other producing bacteria (Reddy et al. 2003, Gao et al. 2013, Singh et al. 2013, Yun et al. 2013). Its PHAs accumulation started at the end of the exponential growth and continued during the stationary phase, (Gumel et al. 2013). This PHAs accumulation was obtained in the presence of an excess of carbon source coupled to a limitation of 
other nutrients. This is the first study about bacteria isolated from soil and fiber of coconut that reported the production of PHAs, which can be a key factor for optimizing the production of biopolymers. Furthermore, it is the first study reporting species from the genus Staphylococcus as PHAs producers. More studies are required to determine if these bacteria are capable of using the fiber of decomposed coconut as carbon substrates to produce PHAs.

\section{CONCLUSIONS}

The current study is the first one to demonstrate that bacteria from Staphylococcus and Bacillus, isolated from soils with wastes of Cocos nucifera fibers, are capable of producing different concentrations of PHAs, which may be a key factor for future studies on PHA production from wastes of coconuts or their fibers.

\section{ACKNOWLEDGMENTS}

We are grateful to Travis Ashworth for critical discussionh on this work. We also thank Roberto Ochoa, Guadalupe Zavala, Augusto Rojas and Jorge Ramos for their technical support.

The authors declare that there is no conflict of interests for the publication of this research paper.

\section{REFERENCES}

Akaraonye E., Keshavarz T. and Roy I. (2010). Production of polyhydroxyalkanoates: the future green materials of choice. J. Chem. Technol. Biotechnol. 85, 732-743. DOI: $10.1002 /$ jctb.2392

Cavalheiro J.M.B.T., De Almeida M.C.M.D., Grandfils C. and Da Fonseca M.M.R. (2009). Poly(3-hydroxybutyrate) production by Cupriavidus necator using waste glycerol. Process Biochem. 44, 509-515.

DOI: $10.1016 /$ j.procbio.2009.01.008

Chen G.Q. (2009). A microbial polyhydroxyalkanoates (PHA) based bio- and materials industry. Chem. Soc. Rev. 38, 2434-2446. DOI: 10.1039/b812677c

Choi J.-I. and Lee S.Y. (1997). Process analysis and economic evaluation for Poly(3-hydroxybutyrate) production by fermentation. Bioprocess. Biosyst. Eng. 17: 335-342. DOI: 10.1007/s004490050394

Gao X., Jian J., Li W.-J., Yang Y.-C., Shen X.-W., Sun Z.-R., Wu Q. and Chen G.-Q. (2013). Genomic study of polyhydroxyalkanoates producing Aeromonas hydrophila 4AK4. Appl. Microbiol. Biotechnol. 97, 9099-9109. DOI: 10.1007/s00253-013-5189-y

González García Y., Meza Contreras J.C., González Reynoso O. and Córdova López J.A. (2013). Síntesis y biodegradación de polihidroxialcanoatos: plásticos de origen microbiano. Rev. Int. Contam. Ambie. 29, 77-115.

Grage K., Jahns A.C., Parlane N., Palanisamy R., Rasiah I. A., Atwood J.A. and Rehm B.H.A. (2009). Bacterial polyhydroxyalkanoate granules: Biogenesis, structure, and potential use as nano-/micro-beads in biotechnological and biomedical applications. Biomacromolecules 1, 660-669. DOI: 10.1021/bm801394s

Gumel A.M., Annuar M.S.M. and Chisti Y. (2013). Recent advances in the production, recovery and applications of polyhydroxyalkanoates. J. Polym. Environ. 21, 580605. DOI: 10.1007/s10924-012-0527-1

Hassan M.A., Yee L.-N., Yee P.L., Ariffin H., Raha A.R., Shirai Y. and Sudesh K. (2013). Sustainable production of polyhydroxyalkanoates from renewable oil-palm biomass. Biomass Bioenerg. 50, 1-9.

DOI: 10.1016/j.biombioe.2012.10.014

Hernández-Flores G., Poggi-Varaldo H.M., Solorza-Feria O., Ponce Noyola M.T., Romero-Castañón T. and Rinderknecht-Seijas N. (2015a). Tafel equation based model for the performance of a microbial fuel cell. Int. J. Hydrogen Energy 40, 17421-17432.

DOI: 10.1016/j.ijhydene.2015.06.119

Hernández-Flores G., Poggi-Varaldo H.M., Solorza-Feria O., Romero-Castañón T., Ríos-Leal E., Galíndez-Mayer J. and Esparza-García F. (2015b). Batch operation of a microbial fuel cell equipped with alternative proton exchange membrane. Int. J. Hydrogen Energy 40, 17323-17331. DOI: 10.1016/j.ijhydene.2015.06.057

Hernández-Flores G., Poggi-Varaldo H.M., SolorzaFeria O. Ponce-Noyola M.T., Romero-Castañón T., Rinderknecht-Seijas N. and Galíndez-Mayer J. (2015c). Characteristics of a single chamber microbial fuel cell equipped with a low cost membrane. Int. J. Hydrogen Energy 40, 17380-17387.

DOI: 10.1016/j.ijhydene.2015.10.024

Hernández-Flores G., Poggi-Varaldo H.M., Solorza-Feria O., Ponce Noyola M.T., Romero-Castañón T. and Rinderknecht-Seijas N. (2015d). Improvement of microbial fuel cell performance by selection of anodic materials and enrichment of inoculum. J. New. Mat. Electrochem. Systems. 18, 121-129.

Kichise T., Taguchi S. and Doi Y. (2002). Enhanced accumulation and changed monomer composition in polyhydroxyalkanoate (PHA) copolyester by In Vitro evolution of Aeromonas caviae PHA synthase. Appl. Environ. Microbiol. 68, 2411-2419.

DOI: 10.1128/AEM.68.5.2411-2419.2002 
Kourmentza C., Ntaikou I., Lyberatos G. and Kornaros M. (2015). Polyhydroxyalkanoates from Pseudomonas sp. using synthetic and olive mill wastewater under limiting conditions. Int. J. Biol. Macromol. 74, 202-210. DOI: 10.1016/j.ijbiomac.2014.12.032

Law J.H. and Slepecky R.A. (1961). Assay of poly-betahydroxybutyric acid. J. Bacteriol. 82, 33-36.

Lee J., Jung S.-G., Park C.-S., Kim H.-Y., Batt C.A. and Kim Y-R (2011). Tumor-specific hybrid polyhydroxybutyrate nanoparticle: Surface modification of nanoparticle by enzymatically synthesized functional block copolymer. Bioorg. Med. Chem. Lett. 21, 29412944. DOI: 10.1016/j.bmcl.2011.03.058

Lee S.Y. (1996). Bacterial polyhydroxyalkanoates. Biotechnol. Bioeng. 49, 1-14. DOI: 10.1002/(SICI)10970290(19960105)49:1<1::AID-BIT1>3.0.CO;2-P

Liu C., Wang H., Xing W. and Wei L. (2013). Composition diversity and nutrition conditions for accumulation of polyhydroxyalkanoate (PHA) in a bacterial community from activated sludge. Appl. Microbiol. Biotechnol. 97, 9377-9387.

DOI: $10.1007 / \mathrm{s} 00253-013-5165-6$

Madison L.L. and Huisman G.W. (1999). Metabolic engineering of poly(3-Hydroxyalkanoates): From DNA to plastic. Microbiol. Mol. Biol. Rev. 63, 21-53.

Mejía-Ruíz H., Moreno S., Guzmán J., Nájera R., León R., Soberón-Chávez G. and Espín G. (1997). Isolation and characterization of a mutant. FEMS Microbiol. Lett. 156, 101-106. DOI: 10.1016/S0378-1097(97)00409-6

Ostle A.G. and Holt J.G. (1982). Nile blue A as a fluorescent stain for poly-beta-hydroxybutyrate. Appl. Environ. Microbiol. 44, 238-241.

Passanha P., Esteves S.R., Kedia G., Dinsdale R.M. and Guwy A.J. (2013). Increasing polyhydroxyalkanoate (PHA) yields from Cupriavidus necator by using filtered digestate liquors. Bioresour. Technol. 147, 345-352. DOI: 10.1016/j.biortech.2013.08.050

Poirier Y., Nawrath C. and Somerville C. (1995). Production of polyhydroxyalkanoates, a family of biodegradable plastics and elastomers in bacteria and plants. Nat. Biotechnol. 13, 142-150. DOI: 10.1038/nbt0295-142

Ponce Andrade G.I., Vázquez Duhalt R., Rodríguez Vázquez R., Medina Ramírez I H., Lozano Álvarez J.A. and Jáuregui Rincón J. (2012). Evidencia de la biodegradación de resinas fenólicas con hongos ligninolíticos por microscopía electrónica de barrido. Rev. Int. Contam. Ambie. 28, 159-166.

Pötter M., Madkour M.H., Mayer F. and Steinbüchel A. (2002). Regulation of phasin expression and polyhydroxyalkanoate (PHA) granule formation in Ralstonia eutropha H16. Microbiology 148, 2413-2426.

Povolo S., Romanelli M.G., Fontana F., Basaglia M. and Casella S. (2012). Production of polyhydroxyalkano- ates from fatty wastes. J. Polym. Environ. 20, 944-949. DOI: $10.1007 / \mathrm{s} 10924-012-0485-7$

Reddy C.S.K., Ghai R. and Kalia V.C. (2003). Polyhydroxyalkanoates: an overview. Bioresour. Technol. 87, 137-146.

Rehm B.H.A. (2003). Polyester synthases: natural catalysts for plastics. Biochem. J. 376, 1-14.

DOI: $10.1042 / B J 20031254$

Sanger F., Nicklen S., and Coulson A.R. (1977). DNA sequencing with chain-terminating inhibitors. Proc. Natl. Acad. Sci. USA. 74, 5463-7.

Segura D. and Espín G. (1998). Mutational inactivation of a gene homologous to Escherichia coli ptsP affects poly-beta-hydroxybutyrate accumulation and nitrogen fixation in Azotobacter vinelandii. J. Bacteriol. 180, 4790-4798.

Shrivastav A., Kim H.-Y. and Kim Y.-R. (2013). Advances in the applications of polyhydroxyalkanoate nanoparticles for novel drug delivery system. Biomed. Res. Int. 2013, 1-12. DOI: 10.1155/2013/581684

Singh M., Kumar P., Patel S.K.S. and Kalia V.C. (2013). Production of polyhydroxyalkanoate co-polymer by Bacillus thuringiensis. Indian J. Microbiol. 53, 77-83. DOI: $10.1007 / \mathrm{s} 12088-012-0294-7$

Slater S., Houmiel K.L., Tran M., Mitsky T.A., Taylor N.B., Padgette S.R. and Gruys K.J. (1998). Multiple beta-ketothiolases mediate poly(beta-hydroxyalkanoate) copolymer synthesis in Ralstonia eutropha. J. Bacteriol. 180, 1979-1987.

Steinbüchel A. and Hein S. (2001). Biochemical and molecular basis of microbial synthesis of polyhydroxyalkanoates in microorganisms. Adv. Biochem. Eng. Biotechnol. 71, 81-123.

Takase K. (2003). Enhanced synthesis of poly(3-hydroxybutyrate) in recombinant Escherichia coli by means of error-prone PCR mutagenesis, saturation mutagenesis, and in vitro recombination of the type II polyhydroxyalkanoate synthase gene. J. Biochem. 133, 139-145. DOI: $10.1093 / \mathrm{jb} / \mathrm{mvg} 015$

Toribio-Jiménez J., Maldonado-Del Moral B., Echeverría S., Ortuño C., Rodríguez-Barrera M.A., Velázquez M.E., Román A., Castellanos M. and Romero-Ramírez Y. (2014). Biotype, antibiotype, genotype and toxin gene tsst-1 in Staphylococcus aureus isolated from Cotija cheese in the state of Guerrero, México. African. J. Microbiol. Research. 8, 2893-2897.

DOI: $10.5897 / A J M R 2014.6797$

Tsuge T., Watanabe S., Shimada D., Abe H., Doi Y. and Taguchi S. (2007). Combination of N149S and D171G mutations in Aeromonas caviae polyhydroxyalkanoate synthase and impact on polyhydroxyalkanoate biosynthesis. FEMS. Microbiol. Lett. 277, 217-222. DOI: 10.1111/j.1574-6968.2007.00958.x 
Van der Walle G.A., de Koning G.J., Weusthuis R.A. and Eggink G. (2001). Properties, modifications and applications of biopolyesters. Adv. Biochem. Eng. Biotechnol. 71, 263-91.

Verlinden R.A.J., Hill D.J., Kenward M.A., Williams C.D. and Radecka I. (2007). Bacterial synthesis of biodegradable polyhydroxyalkanoates. J. Appl. Microbiol. $102,1437-1449$.

DOI: 10.1111/j.1365-2672.2007.03335.x

Yang T.H., Jung Y.K., Kang H.O., Kim T.W., Park S.J. and Lee S.Y. (2011). Tailor-made type II Pseudomonas PHA synthases and their use for the biosynthesis of polylactic acid and its copolymer in recombinant Escherichia coli. Appl. Microbiol. Biotechnol. 90, 603-614.

DOI: $10.1007 / \mathrm{s} 00253-010-3077-2$

Yun J.H., Sawant S.S. and Kim B.S. (2013). Production of polyhydroxyalkanoates by Ralstonia eutroph a from volatile fatty acids. Korean J. Chem. Eng. 30, 22232227. DOI: $10.1007 / \mathrm{s} 11814-013-0190-9$

Zinn M., Witholt B. and Egli T. (2001). Occurrence, synthesis and medical application of bacterial polyhydroxyalkanoate. Adv. Drug. Deliv. Rev. 53, 5-21. DOI: 10.1016/S0169-409X(01)00218-6 